\title{
The 100 most influential publications in paracetamol poisoning treatment: a bibliometric analysis of human studies
}

\author{
Sa'ed H. Zyoud ${ }^{1,2,3^{*}}$, W. Stephen Waring ${ }^{4}$, Samah W. Al-Jabi ${ }^{2}$, Waleed M. Sweileh ${ }^{5}$ and Rahmat Awang ${ }^{3}$
}

\begin{abstract}
Background: Analysis of the most influential publications within paracetamol poisoning treatment can be helpful in recognizing main and novel treatment issues within the field of toxicology. The current study was performed to recognize and describe the most highly cited articles related to paracetamol poisoning treatment.

Methods: The 100 most highly cited articles in paracetamol poisoning treatment were identified from the Scopus database in November 2015. All eligible articles were read for basic information, including total number of citations, average citations per year, authors' names, journal name, impact factors, document types and countries of authors of publications.

Results: The median number of citations was 75 (interquartile range 56-137). These publications were published between 1974 and 2013. The average number of years since publication was 17.6 years, and 45 of the publications were from the 2000s. A significant, modest positive correlation was found between years since publication and the number of citations among the top 100 cited articles $(r=0.316 ; p=0.001)$. A total of 55 journals published these 100 most cited articles. Nine documents were published in Clinical Toxicology, whereas eight documents were published in Annals of Emergency Medicine. Citations per year since publication for the top 100 most-cited articles ranged from 1.5 to 42.6 and had a mean of 8.5 citations per year and a median of 5.9 with an interquartile range of 3.75-10.35. In relation to the origin of the research publications, they were from 8 countries. The USA had the largest number of articles, 47, followed by the UK and Australia with 38 and nine articles respectively.
\end{abstract}

Conclusions: This study is the first bibliometric assessment of the top 100 cited articles in toxicology literature. Interest in paracetamol poisoning as a serious clinical problem continues to grow. Research published in high-impact journals and from high income countries is most likely to be cited in published paracetamol research.

Keywords: Paracetamol, Acetaminophen, N-acetylcysteine, Bibliometric, Citations, Scopus, Poisoning

\section{Background}

$\mathrm{N}$-acetylcysteine (NAC) is a well-established antidote for a paracetamol (acetaminophen) overdose and is highly effective in minimising liver injury if administered promptly. However, NAC is associated with a number of adverse effects, including nausea, vomiting and non-immunoglobulin E anaphylactic (anaphylactoid)

\footnotetext{
*Correspondence: saedzyoud@yahoo.com; saedzyoud@najah.edu

1 Poison Control and Drug Information Center (PCDIC), College of Medicine and Health Sciences, An-Najah National University, Nablus 44839, Palestine

Full list of author information is available at the end of the article
}

reactions (Zyoud et al. 2010c). A number of methods have been applied in clinical practice for risk stratification, such that NAC is administered to patients thought to be at significant risk of paracetamol-induced liver injury. Most prominently, the extent of paracetamol exposure may be estimated from a measured serum concentration at a known interval after ingestion. However, there are difficulties in relying on patient reporting, and errors may occur concerning the reported drug name, dose and timing of ingestion (Zyoud et al. 2012; Hewett et al. 2013; Rutter et al. 2013). A history of acute or chronic alcohol ingestion and biochemical tests of malnutrition have 
been explored as means of detecting an increased susceptibility to paracetamol liver toxicity; however, none of these are sufficiently reliable for routine clinical application (Waring et al. 2008a, b, d; Zyoud et al. 2011).

The original NAC infusion regimen described by Prescott in the late 1970s gives rise to very high initial blood concentrations, which are associated with the development of adverse effects; a number of alternative regimens have been described, which incorporate a slower initial rate of infusion (Prescott et al. 1977; Zyoud et al. 2010a, b; Waring 2012). Novel NAC infusion regimens are associated with a lower rate of occurrence of adverse effects, but too few data are currently available for a comparison of efficacy in preventing paracetamolinduced liver injury (Chiew et al. 2016). Nonetheless, the regulatory authorities in the UK made substantial changes to the NAC Marketing Authorisation in September 2012, incorporating a slower delivery of the initial loading dose of $150 \mathrm{mg}$ per $\mathrm{kg}$, extended from 15 to $60 \mathrm{~min}$. At the same time, amendments were made to the criteria for NAC so that treatment should be considered for any patient that ingests more paracetamol than $75 \mathrm{mg}$ per $\mathrm{kg}$ of body weight or has a measured paracetamol concentration higher than the 100-line nomogram that was formerly used for "high risk" patients only. Other countries have followed suit and incorporated these amendments into local policy. At present, few data exist concerning the impact on rates of occurrence of liver injury or adverse acetylcysteine effects. Early reports from the UK indicate that, since September 2012, there have been increased numbers of patients receiving acetylcysteine, increased hospitalisation and a substantial financial burden (Thompson et al. 2013; Bateman et al. 2014a).

Other novel therapeutic approaches have been examined in patients receiving an intravenous NAC antidote after paracetamol poisoning. For example, co-administration of cimetidine has been found to have no significant effect on patient outcome (Ebrahimi et al. 2015). Co-administration of ondansetron is highly effective in reducing the adverse effects associated with NAC administration, and this might be considered for routine administration in patients at high risk of anaphylactoid reactions, for example those with a history of asthma or previous adverse effects after NAC (Bateman et al. 2014b).

While numerous bibliometric reports have been performed to investigate factors related to research output in the toxicology field (Zyoud et al. 2010b, 2014a, 2015a, b, c, d), to our knowledge, no study has attempted to evaluate the most influential publications within a particular subspecialty in toxicology. The main aim of our study was to identify the 100 most frequently cited articles related to paracetamol poisoning treatment. Therefore, a bibliometric evaluation of scientific literature in a particular field may be used to recognize the impact of influential scholarly work, authors, subjects, countries, etc. The total number of citations that a published article has achieved indicates the importance that published article has on that area of practice. Analysis of the most influential publications within paracetamol poisoning treatment can be helpful in recognizing main and novel treatment issues within the field of toxicology.

\section{Methods \\ Data acquisition}

In November 2015, we used the Scopus database to retrieve the most frequently cited articles on paracetamol poisoning treatment. Scopus is the largest electronic scientific database. It is larger than either MEDLINE or Web of Science and is more accurate than Google Scholar. Furthermore, Scopus is accessible and allows researchers to obtain information and do analysis that might not be readily achievable in MEDLINE or Google Scholar.

The search terms used to retrieve articles related to paracetamol poisoning treatment were elected from previous bibliometric studies related to paracetamol (Robert et al. 2009; Zyoud et al. 2015a, d). The articles entitled with the terms "acetaminophen" or "paracetamol" or "acetamidophenol" or "hydroxyacetanilide" or "tylenol" or " $n$-acetyl-p-aminophenol" or "panadol" or "APAP" or "acephen" were included in the research. Then, the following keywords were entered as terms in the article title or abstract: "poison"" or "overdose" previous terms were followed by "treat" or "antidot" or "detoxification" or "intervention" or "manag". To include all possible publications related to paracetamol treatment, we included the following strategy in addition to the previous one. The following keywords, "NAC" or "acetylcysteine" or " $N$-acetyl-L-cysteine", were entered as terms in the article title or abstract and followed by the following terms: "acetaminophen" or "paracetamol" or "acetamidophenol" or "hydroxyacetanilide" or "tylenol" or " $n$-acetyl- $p$-aminophenol" or "panadol" or "APAP" or "acephen". The Scopus search was conducted by applying the previous strategies of search for all previous years. No limits were placed on the time period for this search. Furthermore, all documents related to paracetamol, with no language restriction, were searched in Scopus database. Wildcard characters were used to include variations of a word by using an asterisk (") to make our search strategy simpler. For example, in the Scopus search engine, when we entered "*toxic", it offered a wildcard character capability, and we got results for toxic, toxicity, toxicant, toxicities, intoxication-briefly, any possible word that might include the five letters (i.e. toxic). 


\section{Data analysis}

We sorted the extracted results from the largest number of citations to the lowest. The results were then evaluated by two independent researchers to extract only the top 100 cited articles related to paracetamol poisoning treatment in human research subjects. Total numbers of citations, average citations per year, authors' names, journal name, impact factors (IF), document types, countries of publication, and number of authors for only the top 100 cited articles were noted. The impact factor was obtained from 2014 Journal Citation Reports ${ }^{\circledR}$ (Thomson Reuters, New York, NY, USA) (Thomson Reuters 2015) for all journals that published the top 100 cited articles. This is useful in clarifying the significance of absolute citation frequencies. This search used the electronic version of this database by ranking the top 100 cited publications using the standard competition ranking (SCR). It is possible that some articles were cited more frequently than others because of the long time elapsed since their publication. Therefore, a citation index was calculated for each article to avoid the bias created by the time elapsed since publication. Citation index is calculated as the average number of citations divided by number of years elapsed since the article was initially published. A Pearson's correlation coefficient test was applied to assess the correlation between the impact factor of the journal or years since publication or citation index and the number of citations for the top 100 cited articles included in the study. This was carried out using Statistical Package for Social Sciences (SPSS) Version 15.0. Descriptive statistics were presented as frequencies, medians and interquartile ranges or averages. $p$ values $<0.05$ were considered statistically significant for all the comparisons.

\section{Results}

\section{Citation count and publication year}

The number of citations for the top 100 cited articles in paracetamol poisoning treatment ranged from 44 to 553 (Mitchell et al. 1974; Gazzard et al. 1975; Prescott et al. 1976, 1977, 1979, 1989; Rumack and Peterson 1978; Prescott 1981, 1983; Rumack et al. 1981; Forrest et al. 1982; Prescott and Critchley 1983; Black 1984; Mant et al. 1984; Rumack 1984, 1986; Seeff et al. 1986; Slattery et al. 1987; Lauterburg and Velez 1988; Smilkstein et al. 1988; Ziment 1988; Burgunder et al. 1989; Dawson et al. 1989; Riggs et al. 1989; Harrison et al. 1990; Murphy et al. 1990; Underhill et al. 1990; Flanagan and Meredith 1991; Harrison et al. 1991; Holdiness 1991; Keays et al. 1991; O'Grady et al. 1991; Penna and Buchanan 1991; Smilkstein et al. 1991; Bray et al. 1992; Jones and Vale 1993; Thomas 1993; Mutimer et al. 1994; Makin et al. 1995; Eguia and Materson 1997; Makin and Williams 1997; Bernal et al. 1998; Jones 1998; Kelly 1998; Mitchell et al.
1998; Perry and Shannon 1998; Anderson et al. 1999; Buckley et al. 1999a, b; Detry et al. 1999; McClain et al. 1999; Prescott 2000; Prince et al. 2000; Whyte et al. 2000; Woo et al. 2000; Ferner et al. 2001; Schmidt and Dalhoff 2001; Ward et al. 2001; Appelboam et al. 2002; Gyamlani and Parikh 2002; Rumack 2002; Schiodt et al. 2002; Schmidt et al. 2002; Wallace et al. 2002; James et al. 2003; Kao et al. 2003; Kozer et al. 2003; Daly et al. 2004; Lee 2004; Lynch and Robertson 2004; Benson et al. 2005; Kerr et al. 2005; Marzullo 2005; Prescott 2005; Sivilotti et al. 2005; Aitio 2006; Dart et al. 2006; Kanter 2006; Mahadevan et al. 2006; Nourjah et al. 2006; Atkuri et al. 2007; Larson 2007; Daly et al. 2008; Dodd et al. 2008; Fontana 2008; Heard 2008; Kortsalioudaki et al. 2008; Mazer and Perrone 2008; Pakravan et al. 2008; Waring et al. 2008c; Chun et al. 2009; James et al. 2009; Lee et al. 2009; Millea 2009; Sandilands and Bateman 2009; Yarema et al. 2009; Winnike et al. 2010; Ferner et al. 2011; Khandelwal et al. 2011; Antoine et al. 2013; Samuni et al. 2013) (see Table 1 for the top 100 cited publications in paracetamol poisoning treatment ranked in descending order of the number of citations). The median number of citations was 75 (interquartile range 56-137). These publications were published between 1974 and 2013. The average number of years since publication was 17.6 years, and 45 of the publications were from the 2000s. A significant, modest positive correlation was found between years since publication and the number of citations among the top 100 cited articles $(r=0.316 ; p=0.001)$. The earliest article was written by Mitchell et al. (1974) almost 41 years ago in Clinical Pharmacology and Therapeutics, and the most recent were published about 2 years ago (2013) by Samuni et al. (2013) and Antoine et al. (2013) in Biochimicaet Biophysica Acta-General Subjects and Hepatology respectively.

\section{Average number of citations per year}

Average number of citations per year for the top 100 cited articles ranged from 1.5 to 42.6 with a mean of 8.5 citations per year and a median of 5.9 (interquartile range 3.75-10.35). Table 2 ranks the top 10 publications based on the highest average number of citations per year. Nine of the articles in the list were published after year 2000 . The top three articles based on average number of citations per year were the followings: "Acetaminopheninduced hepatotoxicity" with 42.6 average number of citations per year, "Mechanistic biomarkers provide early and sensitive detection of acetaminophen-induced acute liver injury at first presentation to hospital" with 42.0 average number of citations per year and "The chemistry and biological activities of $\mathrm{N}$-acetylcysteine" with 38.6 average number of citations per year. Interestingly, the total number of citations was significantly correlated with citation index $(\mathrm{r}=0.485, \mathrm{p}<0.001)$. 


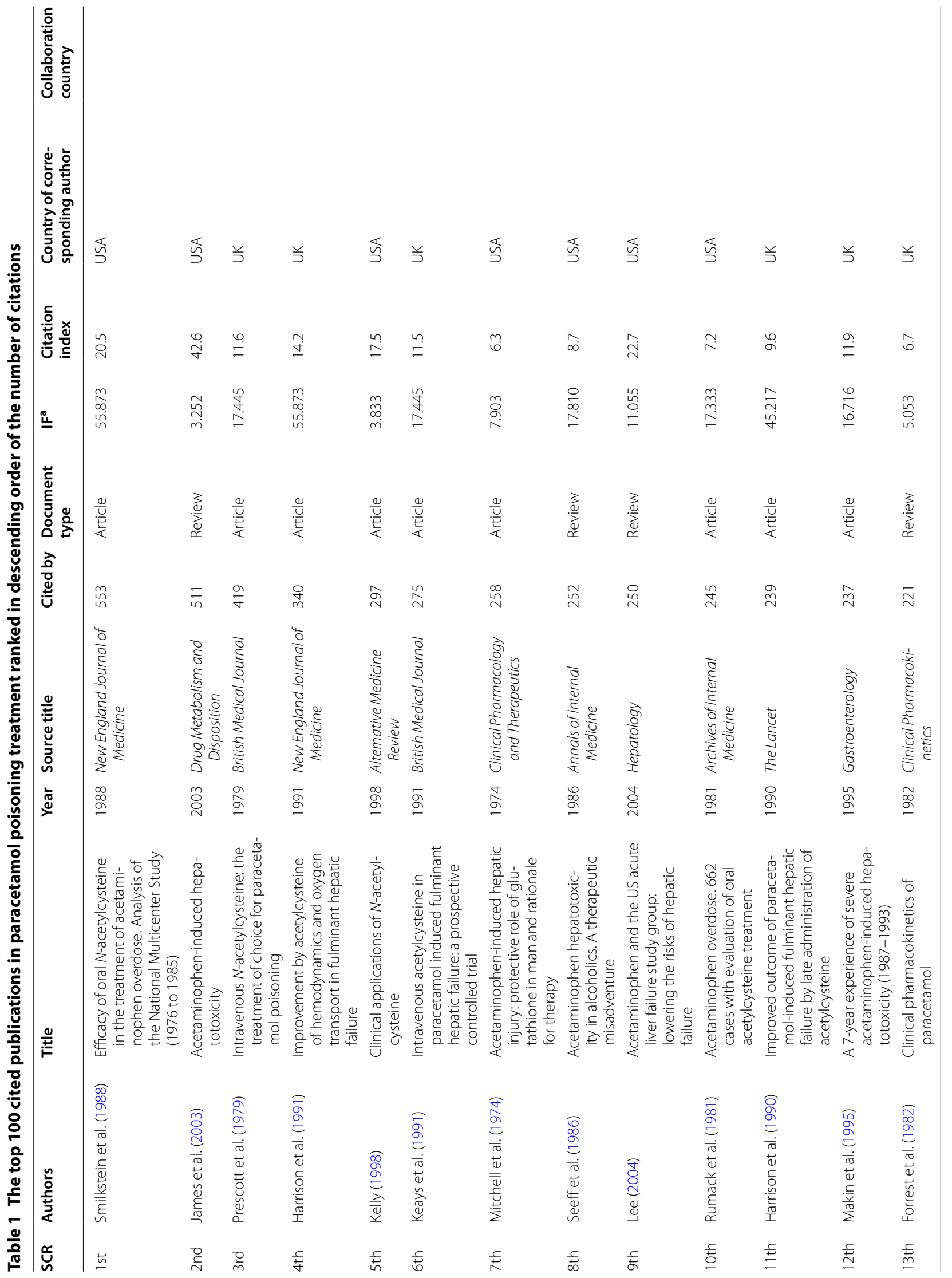




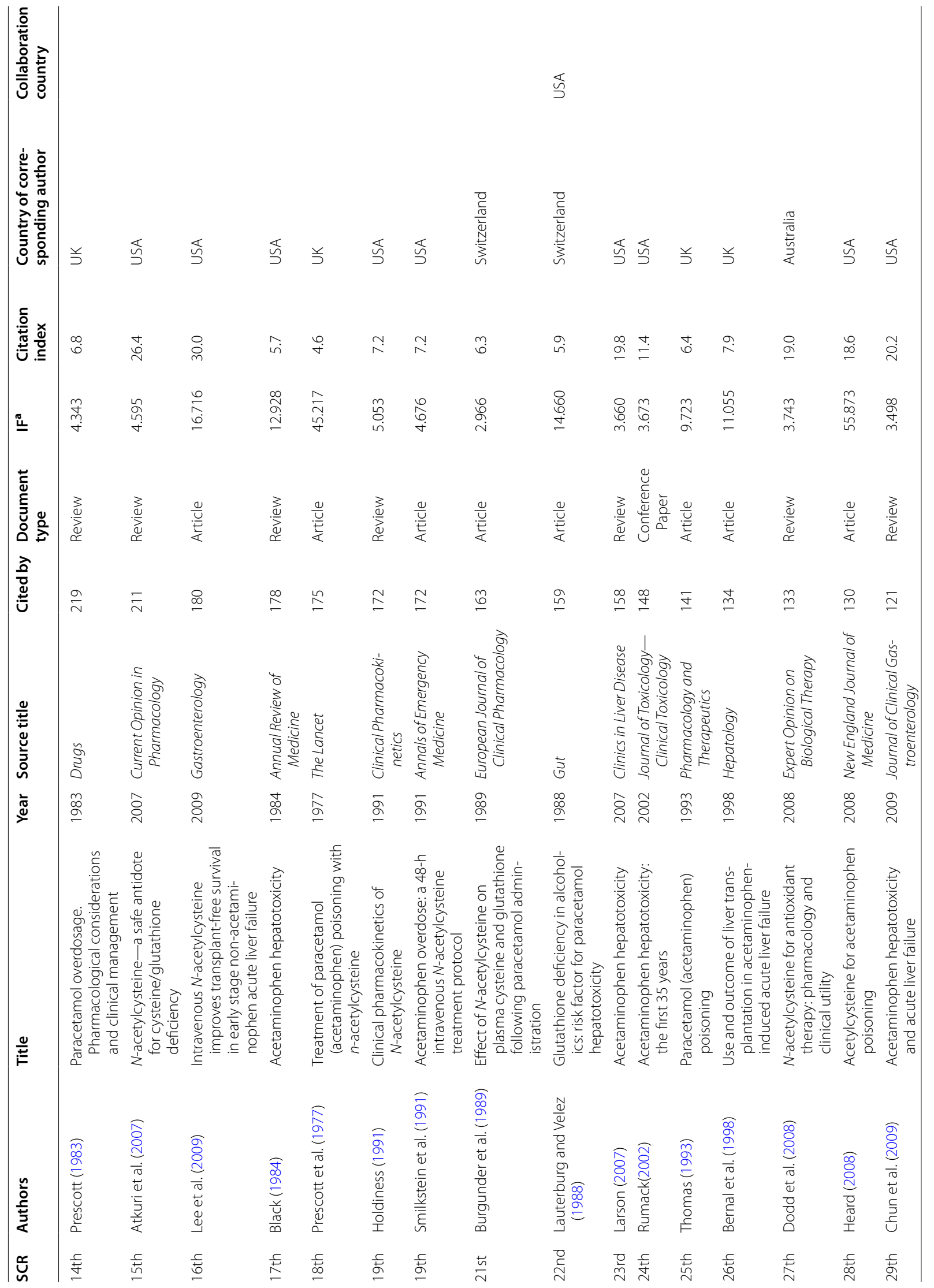




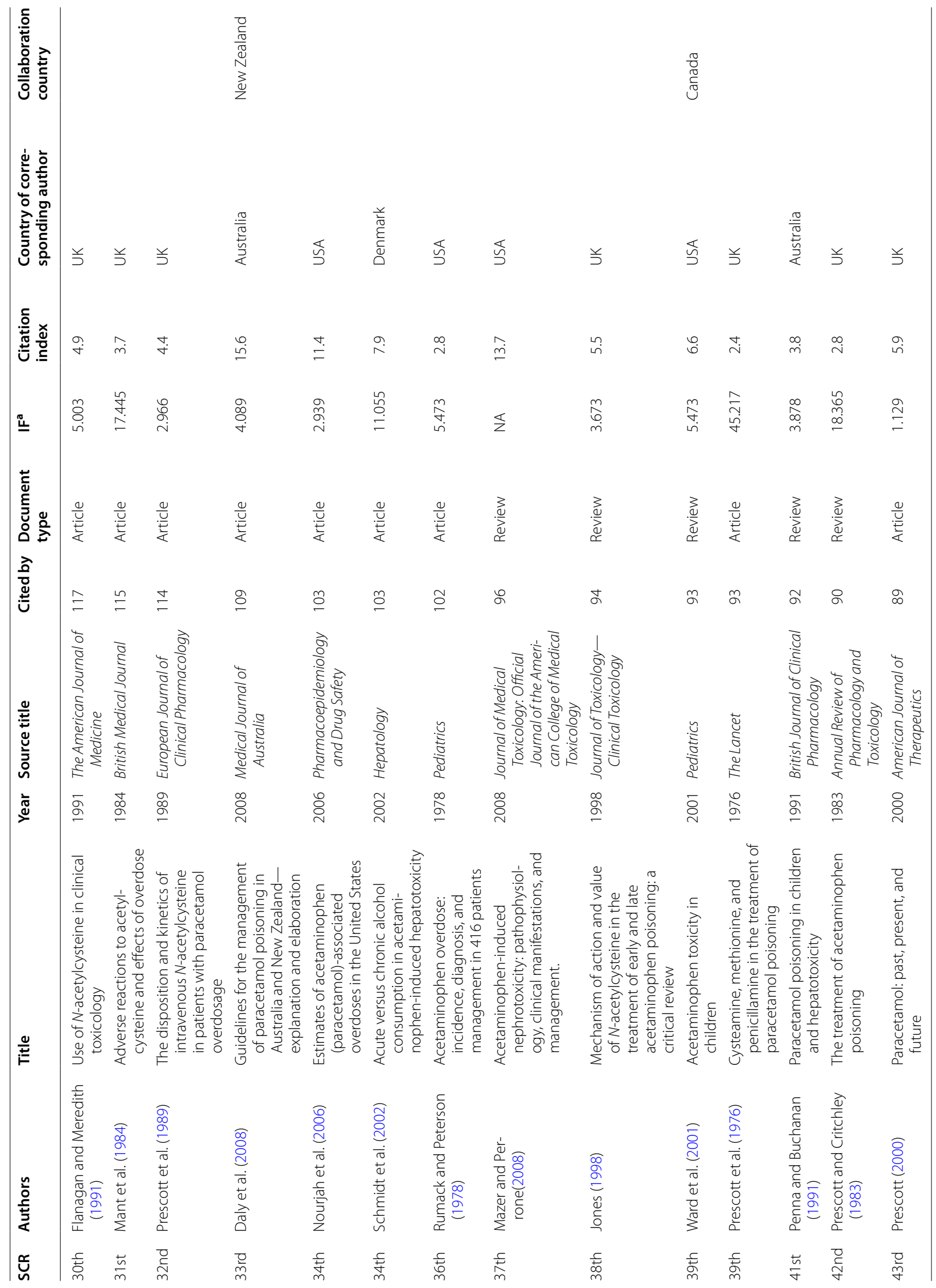




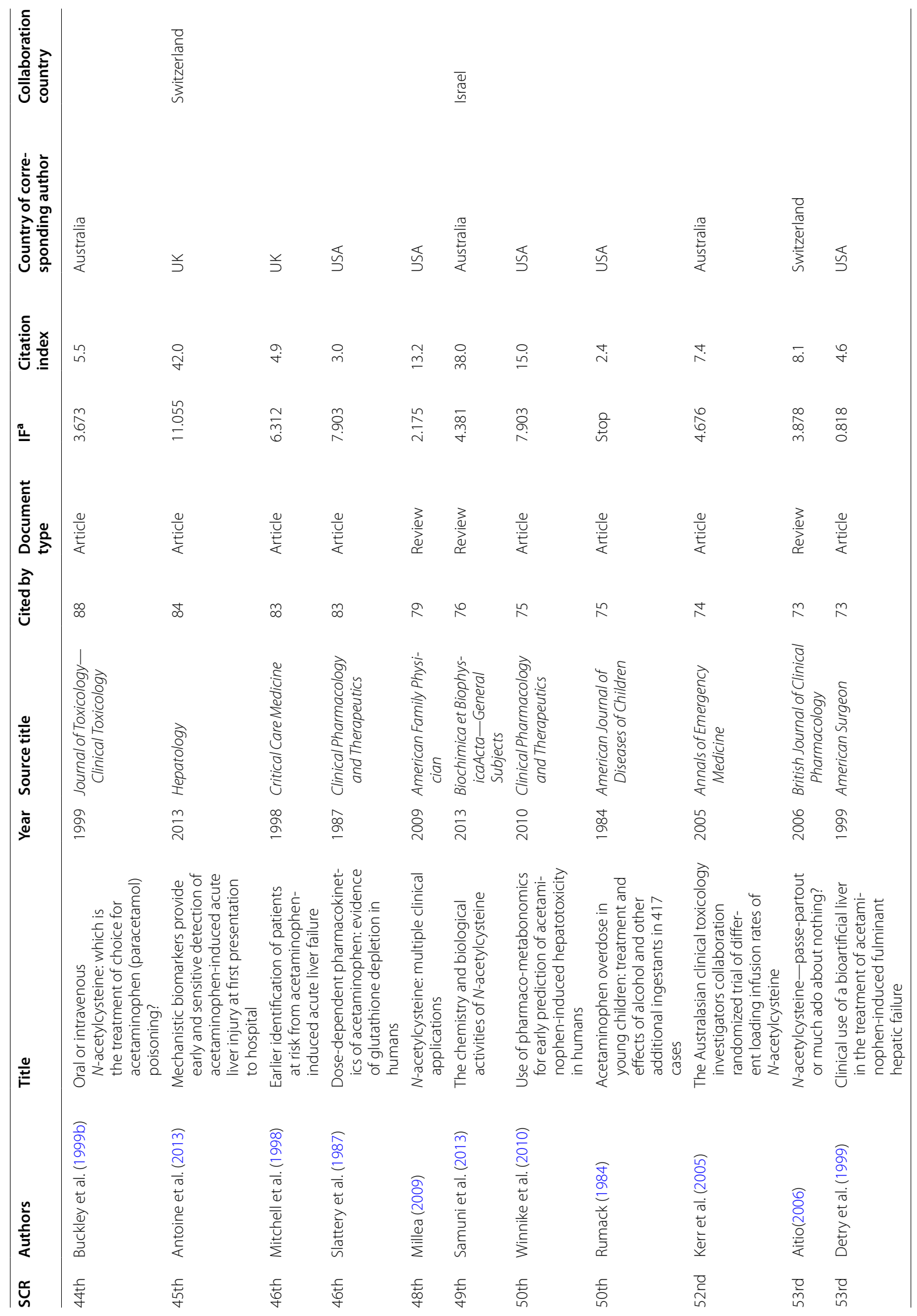




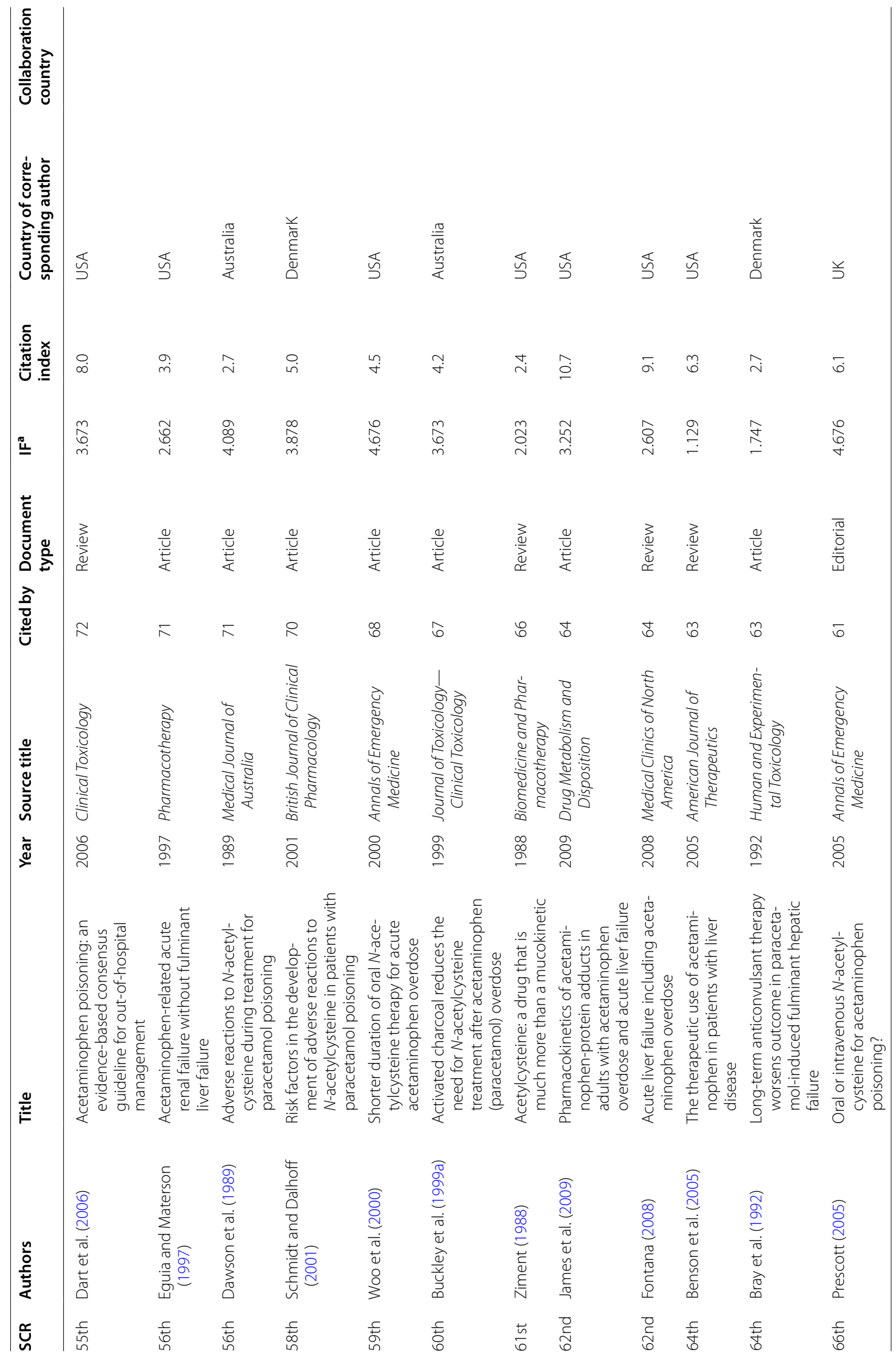




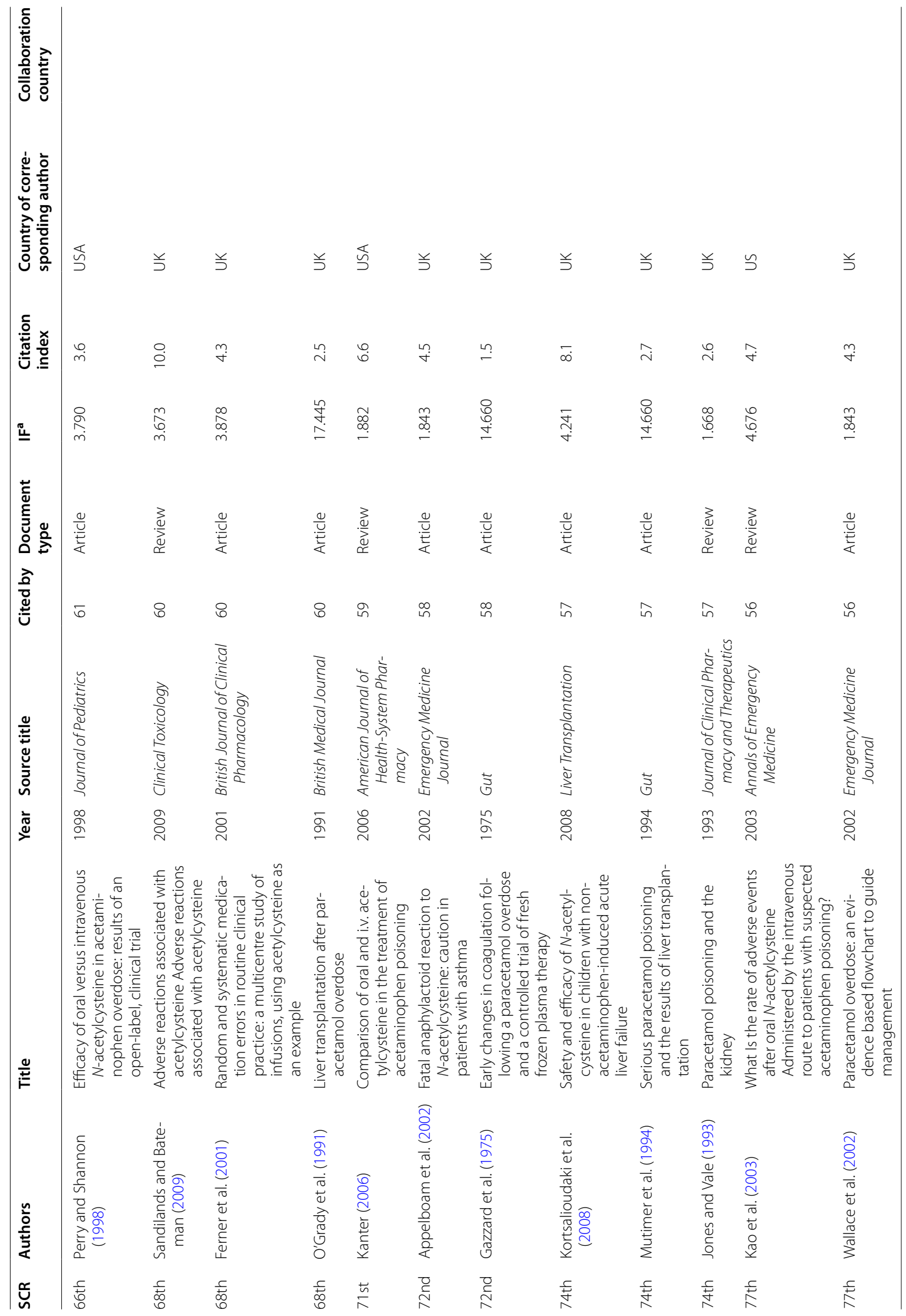




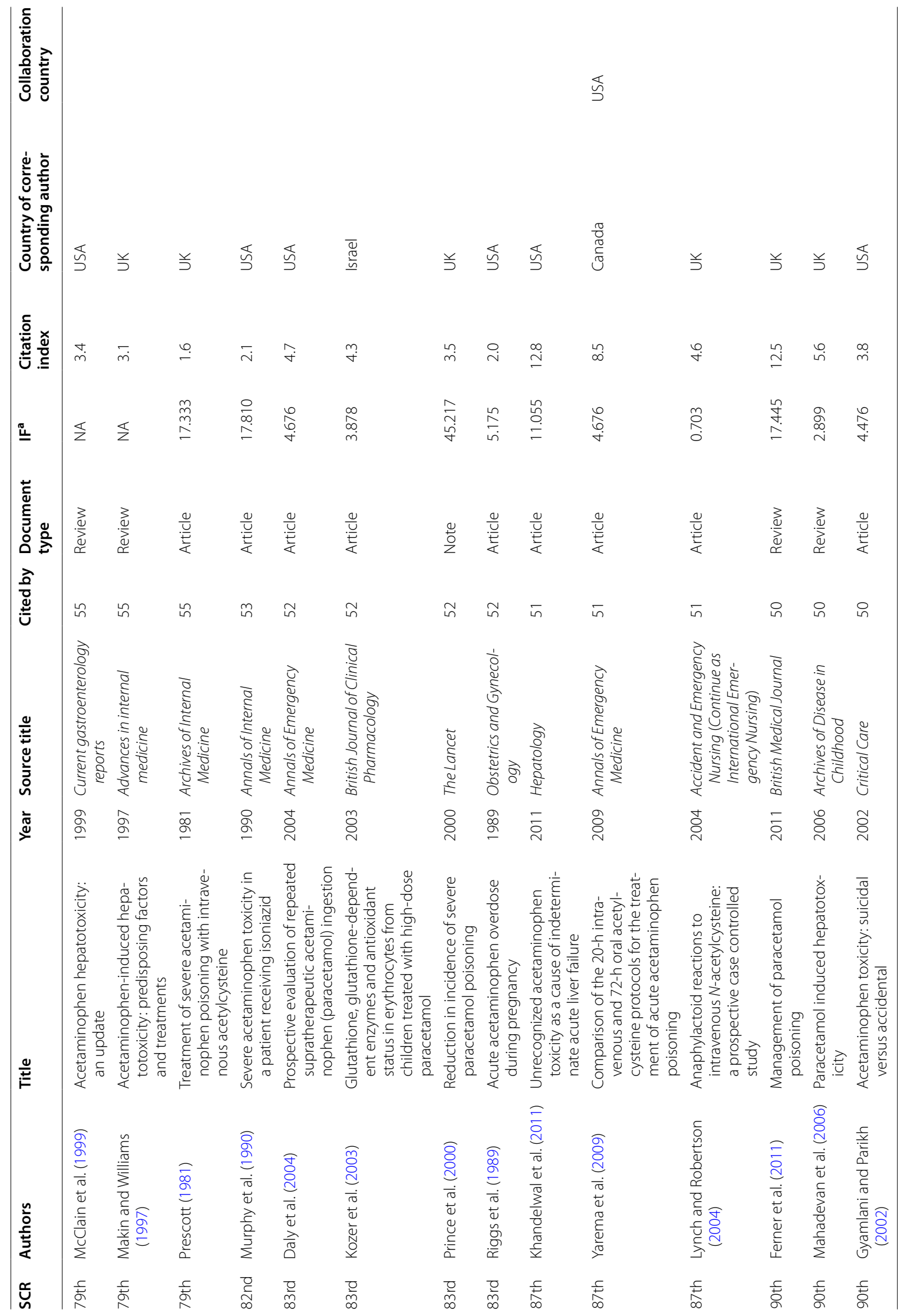




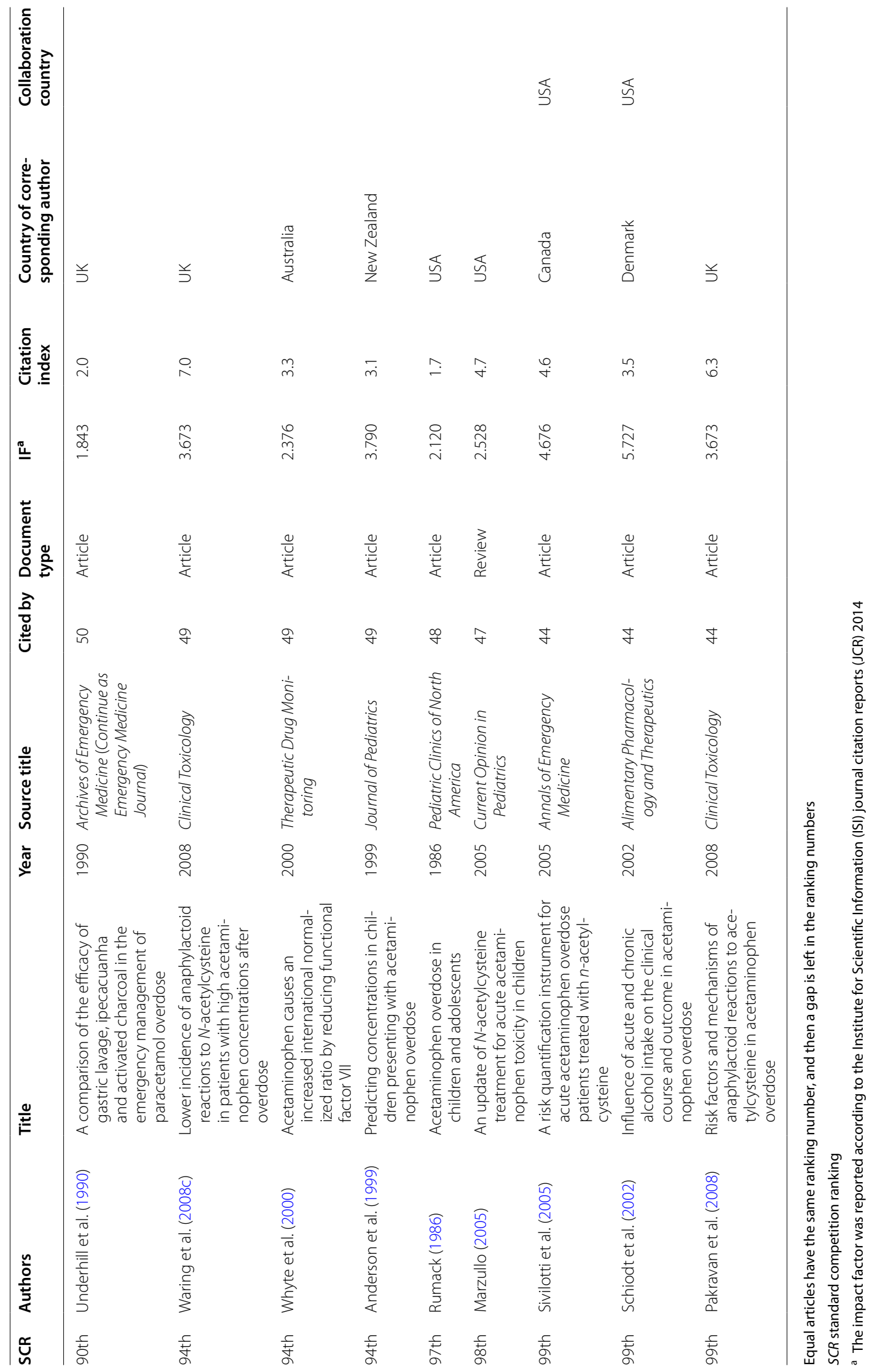




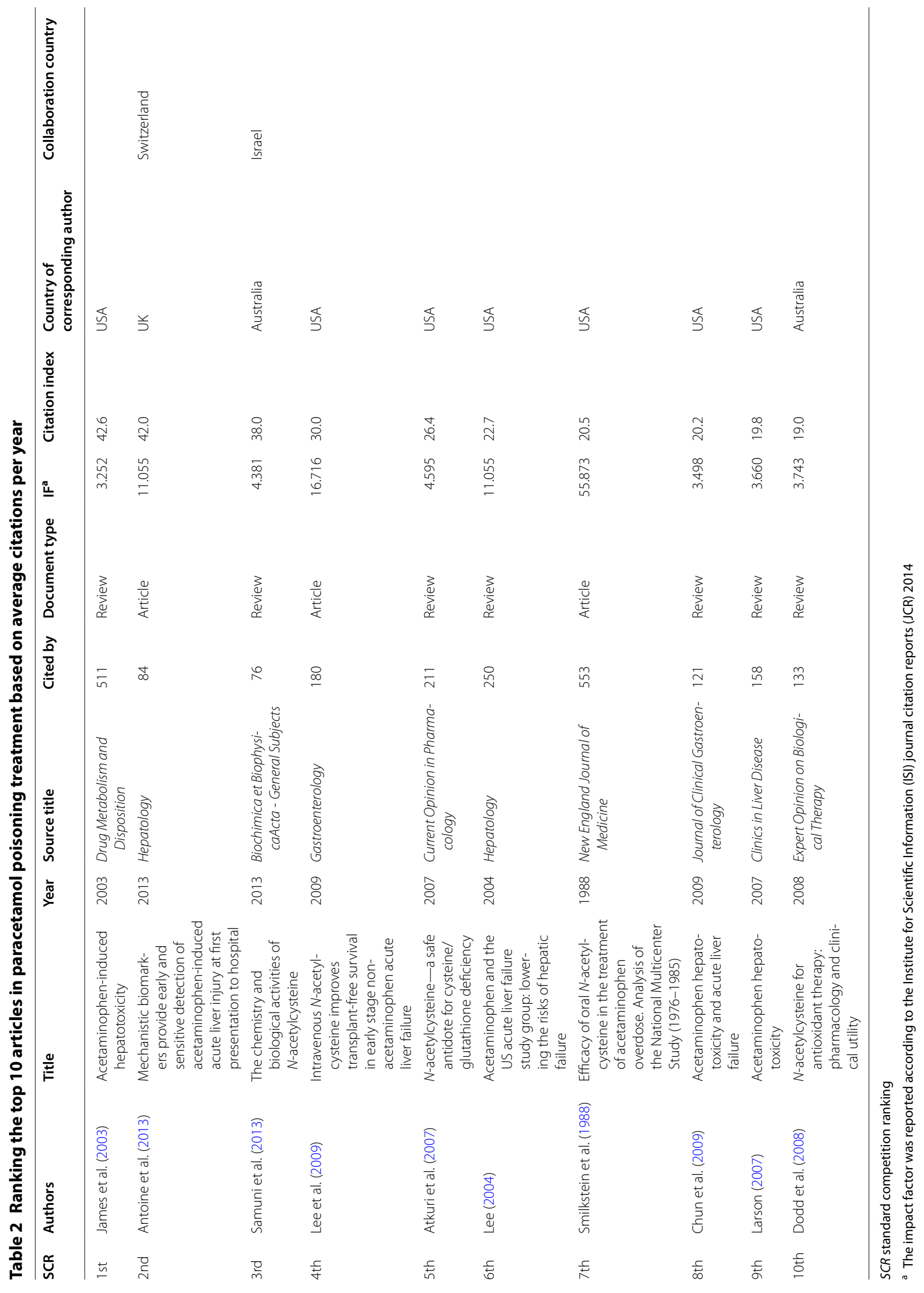




\section{Authorship}

The total number of authors for the top 100 cited articles was 419 , for an average of 4.15 authors per paper. Authors per paper ranged from 1 to 23 , and 20 articles were written by one author. Table 3 ranks the top 10 most prolific authors, who have published at least four publications among the 100 most cited publications.

\section{Journals}

A total of 55 journals published these top 100 cited articles. Nine documents were published in Clinical Toxicology, whereas eight documents were published in Annals of Emergency Medicine and five documents each were published in British Journal of Clinical Pharmacology, Hepatology and British Medical Journal. The impact factor for journals containing the top 100 cited paracetamol poisoning treatment articles ranged from 0.703 to 55.873 . Twenty-eight documents were published in the ten journals with an IF $>10$. Only three journals for the top 100 cited articles were without IF. A significant, modest positive correlation was found between the journal impact factor and the number of citations among the top 100 cited articles $(\mathrm{r}=0.426 ; \mathrm{p}<0.001)$.

\section{Origins and publication type}

In relation to the origin of the research publications for the highly cited articles, they were from eight countries. The USA had the largest number of articles with 47 articles. The UK and Australia published 38 and nine articles respectively, whereas Denmark, Switzerland, Canada, New Zealand and Israel published four, four, three, two and two articles respectively. In the terms of "collaboration with other countries", we found that eight articles were published and co-authored by researchers from multiple countries. Sixty-six articles were original articles, 32 articles were review articles and three were other types of publications, including conference papers, editorials and notes.

\section{Discussion}

The present study was designed to rank and characterize the top 100 cited publications in the field of paracetamol poisoning treatment. The most obvious finding to emerge from this study is that results of this study may explain how developments in this area of clinical toxicology have progressed over time. It becomes obvious which key publications and authors have made exceptional contributions that have played an integral role in shaping the guidelines related to the treatment of paracetamol. Furthermore, the results of this study enhance our understanding about the leading publications that have contributed to the development of this field of toxicology.

Common treatment guidelines for paracetamol poisoning that are currently in use include Australian and New Zealand guideline by Daly et al. (2008), USA guideline by Dart et al. (2006) and UK guideline by Wallace et al. (2002). These guidelines ranked 33rd, 55th and 77th respectively. Furthermore, these common guidelines were based on several articles in the top 100 cited publications such as Smilkstein et al. (1988), Prescott et al. (1979), Keays et al. (1991), Prescott et al. (1977), Rumack (2002), and Smilkstein et al. (1991).

The top 100 cited studies in our study were published from 1974 to 2013 with a citation range of 44-553 times since publication. Compared to citations in other medical

\section{Table 3 The top 10 ranking of prolific authors who published most frequently cited publications, with their affiliations}

\begin{tabular}{|c|c|c|c|}
\hline SCR & Author & $\begin{array}{l}\text { No. of } \\
\text { publications }\end{array}$ & Affiliation \\
\hline $1 \mathrm{st}$ & Prescott, L. & 10 & University of Edinburgh, Edinburgh, Scotland, UK \\
\hline $1 \mathrm{st}$ & Williams, R. & 10 & Foundation for Liver Research, Institute of Hepatology, London, UK \\
\hline $3 r d$ & Rumack, B. H. & 9 & Department of Emergency Medicine, University of Colorado School of Medicine, Aurora, CO, USA \\
\hline 4 th & Wendon, J. & 6 & Institute of Liver Studies at King's College School of Medicine at King's College Hospital, London, UK \\
\hline 5 th & Bateman, D. N. & 5 & University of Edinburgh, Edinburgh, UK \\
\hline 5 th & Buckley, N. & 5 & $\begin{array}{l}\text { Department of Pharmacology, School of Medical Sciences, University of Sydney, Sydney, New South } \\
\text { Wales, Australia }\end{array}$ \\
\hline 5 th & Dawson, A. & 5 & NSW Poisons Information Center, Westmead Children's Hospital Sydney, Australia \\
\hline 5 th & Lee, W. M. & 5 & $\begin{array}{l}\text { Division of Digestive and Liver Diseases, University of Texas Southwestern Medical Center at Dallas, } 5959 \\
\text { Harry Hines Boulevard, Suite 420, Dallas, TX 75390-8887, USA }\end{array}$ \\
\hline 9th & $\begin{array}{l}\text { Alexander, } \\
\text { G.J.M. }\end{array}$ & 4 & Institute of Liver Studies, King's College School of Medicine and Dentistry, London, UK \\
\hline 9th & Harrison, P.M. & 4 & Institute of Liver Studies, King's College Hospital, Denmark Hill, London, UK \\
\hline 9th & Whyte, I.M. & 4 & Calvary Mater Newcastle, Newcastle, NSW, Australia \\
\hline
\end{tabular}

SCR standard competition ranking 
fields, this occupies a low position; in tuberculosis, the number of citations for top-cited studies ranged from 366 to 4443 (Chen et al. 2015), compared to 582-7248 for hypertension (Oh and Galis 2014). The difference in the total number of citations in each area reveals the number of researchers working in each area (Chen et al. 2015). It is also well known that editors for the main journals with high IFs consider articles with a high citation rate to sustain the IF progress of their journals (Zyoud et al. 2014a, b, 2015a, b, d). Furthermore, since the toxicology field is considered as a very narrow field with a very small readership and number of researchers, it should not be surprising for toxicology topics or toxicology journals to have a small numbers of citations (Bird 2008; Zyoud et al. 2014b). Our results confirm that there was a modest relationship between the number of years elapsed since the time of publication and the number of citations. These results support previous findings which reported that older articles attained more citations because their citable period was longer (Loonen et al. 2008; Lefaivre et al. 2011; Aminian et al. 2014; Joyce et al. 2014; Lee et al. 2015). The annual total number of citations for any article fluctuates with time and for some articles the total annual number of citations might decrease with time while for other articles, the total annual number of citations might increase or remain steady with time. In our study, the low correlation between the total citations and citation index seems to be related to papers that have many citations when they are first published but then drop off in later years because researchers might be tended to preferentially cite the most recent studies (Azer and Azer 2016). Our study showed that the average number of citations per year for articles published after year 2000 was higher than those published before 2000 . This finding may be due to the tendency of authors to cite recent papers which is a common practice among authors (Van Noorden et al. 2014).

The most influential article in paracetamol poisoning treatment was conducted by Smilkstein and experts from the USA (Smilkstein et al. 1988) and was published in 1988 in New England Journal of Medicine. This article described the final outcomes of 2540 patients with paracetamol overdose treated with a loading dose of $140 \mathrm{mg}$ per kg of oral NAC followed by 70 mg per kg given every $4 \mathrm{~h}$ for an additional 17 doses. It was concluded that NAC treatment should be started within $8 \mathrm{~h}$ of an paracetamol overdose (Smilkstein et al. 1988). In contrast to earlier findings, recently, in the last decade, described novel NAC infusion regimens offer different rates of intravenous NAC administration in both the loading and maintenance doses, and this is associated with a lower rate of the occurrence of adverse effects (Pakravan et al. 2008; Waring et al. 2008c). These studies were in the list of influential papers in the top 100 cited articles.
The first paper for paracetamol poisoning treatment was cited only 25 times and was published by Maclean et al. (1968) in 1968 in The Lancet. This article recommended immediate gastric lavage, intravenous hydrocortisone, forced diuresis and antihistamine for paracetamol poisoning treatment. This article achieved a low rate of citation to be listed in the top 100 cited publications in the field of paracetamol poisoning treatment because it was based on treatment regimens, which limited recommendations for the treatment of such cases. The two pioneering publications in the field of general paracetamol poisoning were conducted by Mitchell et al. (1973a, b). They explained the mechanism of paracetamol hepatotoxicity, were published in Journal of Pharmacology and Experimental Therapeutics and are considered as remarkable papers in paracetamol poisoning (Rumack and Bateman 2012). These two publications achieved higher citations in the field of general paracetamol poisoning than in the field of paracetamol poisoning treatment, 1052 and 904 citations each respectively (data not shown), but did not appear in our list because they involved animal research. What is surprising is that this group was in our list and got an advanced position (i.e. the seventh most frequently cited paper) by providing a rationale for therapy in humans by indicating that cysteamine could prevent hepatotoxicity (Mitchell et al. 1974). Prescott et al. (1974) reported the successful treatment of patients with severe paracetamol overdose with cysteamine, but this article was not among the top 100 cited articles. This might be due to the adverse effects in patients making it a less than ideal antidote and of low interest to researchers. Surprisingly, Prescott et al. (1979) were found to be in the list of the top 100 cited articles for a different article, which achieved the third position in the list. They reported that intravenous NAC was more effective in the treatment of paracetamol poisoning than cysteamine and methionine and was markedly free from adverse effects (Prescott et al. 1979). Furthermore, it is somewhat surprising that Prescott and his colleagues in Edinburgh published a series of influential papers in the top 100 cited articles (Prescott et al. 1976, 1977, 1989; Prescott 1983, 2000, 2005; Prescott and Critchley 1983).

One of the pioneering article in the field of general paracetamol poisoning was written by Rumack and Matthew (1975). This article is considered as one of the highly cited articles in the field of general paracetamol poisoning, rather than in the field of paracetamol poisoning treatment. It achieved 303 citations (data not shown) but did not appear in our list. Contrary to expectations, several studies (Schiodt et al. 1997; Larson et al. 2005) were dropped from the list of the top 100 cited articles in the field of paracetamol poisoning treatment because these studies did not mention paracetamol poisoning related treatment terms in their titles or abstract. The most 
obvious finding to emerge from our study is that Rumack published a series of influential papers in the top 100 cited articles (Rumack and Peterson 1978; Rumack et al. 1981; Rumack 1984, 1986, 2002).

In the present study, 28 documents were published in the ten journals with an IF >10, including New England Journal of Medicine, The Lancet, Annual Review of Pharmacology and Toxicology, Annals of Internal Medicine, British Medical Journal, Archives of Internal Medicine, Gastroenterology, Gut, Annual Review of Medicine and Hepatology. Our results confirm the modes relationship between the journal impact factor and the number of citations among the top 100 cited articles. These results seem to be consistent with other research, which found that the most cited articles in the field of tuberculosis are often published in journals that top the impact factor list (Chen et al. 2015). The results of our study show that more than half of the publications originated from the USA, followed by the UK. These results match those observed in earlier studies (Loonen et al. 2008; Joyce et al. 2014; Oh and Galis 2014; Chen et al. 2015; Dolan et al. 2015). Research activity in these countries is most likely due to their economic strength (Li et al. 2013; Yun et al. 2015), or numerous large poison centers (Forrester 2016), or the number of researchers or general research activity in this scientific field (Zyoud et al. 2015a, d), or number of poisoning incidents in these countries (Bateman 2014; Mowry et al. 2015).

There are several limitations of this study. First, our analysis to choose publications with a primary focus on paracetamol poisoning treatment research likely excluded articles that had otherwise notably influenced thinking in the field, including some of the highly cited articles that refer to investigations of paracetamol poisoning in animals or in vitro. Second, it was based on the Scopus database alone; Scopus does not index all journals, and we may have missed journals that figure in other databases such as Google Scholar. Third, articles published in recent years had less of a chance to be among the top 100 cited articles because less time has elapsed since the date of publication to allow citation. Another limitation is that some publications did not mention paracetamol poisoning related treatment terms in their titles or abstract, so it is possible that not all publications about paracetamol were considered. The present study design means that we are unable to include some clinicians that have influenced the treatment of paracetamol poisoning through other means, including unpublished research work, presentations at scientific meetings, and pioneering clinical practice. For example, many influential toxicologists, such as Matthew H., Jaeschke H., Piperno E. and Khairallah E.A. (Rumack 2002; Proudfoot and Prescott 2009; Rumack and Bateman 2012), were not identified in our study.
In conclusion, we carried out a bibliometric analysis of the most cited publications focused on paracetamol poisoning research, revealing a number of characteristics related to these influential publications, including the country of origin, type of study, journal and authorship. This study is the first bibliometric assessment of the top 100 cited articles in toxicology literature. The most influential report in paracetamol poisoning treatment research appears to be conducted by Smilkstein et al. from the USA and was published by in 1988 in New England Journal of Medicine. Interest in paracetamol poisoning as a serious clinical problem continues to grow. Research published in high-impact journals and from high income countries is most likely to be cited in published paracetamol research.

\section{Abbreviations}

NAC: N-acetylcysteine; SPSS: Statistical Package for Social Sciences; ISI: Institute for Scientific Information; JCR: Journal Citation Reports; IFs: impact factors; SCR: standard competition ranking.

\section{Authors' contributions}

SZ led the study design, data collection, statistical analysis, and drafting of the manuscript, SA, WS and RA participated in the study design, and revised the article for important intellectual content, and WW wrote part of the article and revised the article for important intellectual content. All authors read and approved the final manuscript.

\section{Author details \\ ${ }_{1}^{1}$ Poison Control and Drug Information Center (PCDIC), College of Medicine and Health Sciences, An-Najah National University, Nablus 44839, Palestine. ${ }^{2}$ Department of Clinical and Community Pharmacy, College of Medicine and Health Sciences, An-Najah National University, Nablus 44839, Palestine. ${ }^{3}$ WHO Collaborating Centre for Drug Information, National Poison Centre, Universiti Sains Malaysia (USM), 11800 Pulau Pinang, Penang, Malaysia. ${ }^{4}$ Acute Medical Unit, York Teaching Hospitals NHS Foundation Trust, Wigginton Road, York YO31 8HE, UK. ${ }^{5}$ Department of Pharmacology and Toxicology, College of Medicine and Health Sciences, An-Najah National University, Nablus 44839, Palestine.}

\section{Competing interests}

The author declares that they have no competing interests.

\section{Ethics approval and consent to participate}

As a bibliometric study, as there were no patients involved in this type of analysis, there was no need for Institutional Review Board approval and it was exempted based upon the design of this study.

Received: 30 April 2016 Accepted: 6 September 2016

Published online: 13 September 2016

\footnotetext{
References

Aitio ML (2006) N-acetylcysteine-passe-partout or much ado about nothing? Br J Clin Pharmacol 61(1):5-15

Aminian A, Daigle CR, Brethauer SA, Schauer PR (2014) Citation classics: top 50 cited articles in bariatric and metabolic surgery. Surg Obes Rel Dis 10(5):898-905

Anderson BJ, Holford NH, Armishaw JC, Aicken R (1999) Predicting concentrations in children presenting with acetaminophen overdose. J Pediatr 135(3):290-295

Antoine DJ, Dear JW, Lewis PS, Platt V, Coyle J, Masson M, Thanacoody RH, Gray AJ, Webb DJ, Moggs JG, Bateman DN, Goldring CE, Park BK
} 
(2013) Mechanistic biomarkers provide early and sensitive detection of acetaminophen-induced acute liver injury at first presentation to hospital. Hepatology 58(2):777-787

Appelboam AV, Dargan PI, Knighton J (2002) Fatal anaphylactoid reaction to $\mathrm{N}$-acetylcysteine: caution in patients with asthma. Emerg Med J 19(6):594-595

Atkuri KR, Mantovani JJ, Herzenberg LA, Herzenberg LA (2007) N-acetylcysteine - a safe antidote for cysteine/glutathione deficiency. Curr Opin Pharmacol 7(4):355-359

Azer SA, Azer S (2016) Bibliometric analysis of the top-cited gastroenterology and hepatology articles. BMJ Open 6(2):e009889

Bateman DN (2014) Pack size and paracetamol overdose: 16 years later. Clin Toxicol 52(8):821-823

Bateman DN, Dear JW, Carroll R, Pettie J, Yamamoto T, Elamin ME, Peart L, Dow M, Coyle J, Gray A, Dargan PI, Wood DM, Eddleston M, Thomas SH (2014a) Impact of reducing the threshold for acetylcysteine treatment in acute paracetamol poisoning: the recent United Kingdom experience. Clin Toxicol 52(8):868-872

Bateman DN, Dear JW, Thanacoody HK, Thomas SH, Eddleston M, Sandilands EA, Coyle J, Cooper JG, Rodriguez A, Butcher I, Lewis SC, Vliegenthart AD, Veiraiah A, Webb DJ, Gray A (2014b) Reduction of adverse effects from intravenous acetylcysteine treatment for paracetamol poisoning: a randomised controlled trial. Lancet 383(9918):697-704

Benson GD, Koff RS, Tolman KG (2005) The therapeutic use of acetaminophen in patients with liver disease. Am J Ther 12(2):133-141

Bernal W, Wendon J, Rela M, Heaton N, Williams R (1998) Use and outcome of liver transplantation in acetaminophen-induced acute liver failure. Hepatology 27(4):1050-1055

Bird SB (2008) Journal impact factors, h indices, and citation analyses in toxicology. J Med Toxicol 4(4):261-274

Black M (1984) Acetaminophen hepatotoxicity. Annu Rev Med 35:577-593

Bray GP, Harrison PM, O'Grady JG, Tredger JM, Williams R (1992) Long-term anticonvulsant therapy worsens outcome in paracetamol-induced fulminant hepatic failure. Hum Exp Toxicol 11(4):265-270

Buckley NA, Whyte IM, O'Connell DL, Dawson AH (1999a) Activated charcoal reduces the need for $\mathrm{N}$-acetylcysteine treatment after acetaminophen (paracetamol) overdose. J Toxicol Clin Toxicol 37(6):753-757

Buckley NA, Whyte IM, O'Connell DL, Dawson AH (1999b) Oral or intravenous $\mathrm{N}$-acetylcysteine: which is the treatment of choice for acetaminophen (paracetamol) poisoning? J Toxicol Clin Toxicol 37(6):759-767

Burgunder JM, Varriale A, Lauterburg BH (1989) Effect of N-acetylcysteine on plasma cysteine and glutathione following paracetamol administration. Eur J Clin Pharmacol 36(2):127-131

Chen LM, Liu YQ, Shen JN, Peng YL, Xiong TY, Tong X, Du L, Zhang YG (2015) The 100 top-cited tuberculosis research studies. Int J Tuberc Lung Dis 19(6):717-722

Chiew AL, Isbister GK, Duffull SB, Buckley NA (2016) Evidence for the changing regimens of acetylcysteine. Br J Clin Pharmacol 81(3):471-481

Chun LJ, Tong MJ, Busuttil RW, Hiatt JR (2009) Acetaminophen hepatotoxicity and acute liver failure. J Clin Gastroenterol 43(4):342-349

Daly FF, O'Malley GF, Heard K, Bogdan GM, Dart RC (2004) Prospective evaluation of repeated supratherapeutic acetaminophen (paracetamol) ingestion. Ann Emerg Med 44(4):393-398

Daly FF, Fountain JS, Murray L, Graudins A, Buckley NA (2008) Guidelines for the management of paracetamol poisoning in Australia and New Zealand-explanation and elaboration. A consensus statement from clinical toxicologists consulting to the Australasian poisons information centres. Med J Aust 188(5):296-301

Dart RC, Erdman AR, Olson KR, Christianson G, Manoguerra AS, Chyka PA, Caravati EM, Wax PM, Keyes DC, Woolf AD, Scharman EJ, Booze LL, Troutman WG (2006) Acetaminophen poisoning: an evidence-based consensus guideline for out-of-hospital management. Clin Toxicol 44(1):1-18

Dawson AH, Henry DA, McEwen J (1989) Adverse reactions to N-acetylcysteine during treatment for paracetamol poisoning. Med J Aust 150(6):329-331

Detry O, Arkadopoulos N, Ting P, Kahaku E, Watanabe FD, Rozga J, Demetriou AA (1999) Clinical use of a bioartificial liver in the treatment of acetaminophen-induced fulminant hepatic failure. Am Surg 65(10):934-938

Dodd S, Dean O, Copolov DL, Malhi GS, Berk M (2008) N-acetylcysteine for antioxidant therapy: pharmacology and clinical utility. Expert Opin Biol Ther 8(12):1955-1962
Dolan RS, Hanna TN, Warraich GJ, Johnson JO, Khosa F (2015) The top 100 articles in the radiology of trauma: a bibliometric analysis. Emerg Radiol 22(6):667-675

Ebrahimi M, Mousavi SR, Toussi AG, Reihani H, Bagherian F (2015) Comparing the therapeutic effectiveness of $\mathrm{N}$-acetylcysteine with the combination of $\mathrm{N}$-acetyl cysteine and cimetidine in acute acetaminophen toxicity: a double-blinded clinical trial. Electron Physician 7(6):1310-1317

Eguia L, Materson BJ (1997) Acetaminophen-related acute renal failure without fulminant liver failure. Pharmacotherapy 17(2):363-370

Ferner RE, Langford NJ, Anton C, Hutchings A, Bateman DN, Routledge PA (2001) Random and systematic medication errors in routine clinical practice: a multicentre study of infusions, using acetylcysteine as an example. Br J Clin Pharmacol 52(5):573-577

Ferner RE, Dear JW, Bateman DN (2011) Management of paracetamol poisoning. BMJ 342:d2218

Flanagan RJ, Meredith TJ (1991) Use of N-acetylcysteine in clinical toxicology. Am J Med 91(3C):131S-139S

Fontana RJ (2008) Acute liver failure including acetaminophen overdose. Med Clin N Am 92(4):761-794

Forrest JA, Clements JA, Prescott LF (1982) Clinical pharmacokinetics of paracetamol. Clin Pharmacokinet 7(2):93-107

Forrester MB (2016) Bibliometric analysis of poison center-related research published in peer-review journals. Hum Exp Toxicol 35(7):705-712

Gazzard BG, Henderson JM, Williams R (1975) Early changes in coagulation following a paracetamol overdose and a controlled trial of fresh frozen plasma therapy. Gut 16(8):617-620

Gyamlani GG, Parikh CR (2002) Acetaminophen toxicity: suicidal vs. accidental. Crit Care 6(2):155-159

Harrison PM, Keays R, Bray GP, Alexander GJ, Williams R (1990) Improved outcome of paracetamol-induced fulminant hepatic failure by late administration of acetylcysteine. Lancet 335(8705):1572-1573

Harrison PM, Wendon JA, Gimson AE, Alexander GJ, Williams R (1991) Improvement by acetylcysteine of hemodynamics and oxygen transport in fulminant hepatic failure. N Engl J Med 324(26):1852-1857

Heard KJ (2008) Acetylcysteine for acetaminophen poisoning. N Engl J Med 359(3):285-292

Hewett DG, Shields J, Waring WS (2013) Missed paracetamol (acetaminophen) overdose due to confusion regarding drug names. Curr Drug Saf 8(3):203-206

Holdiness MR (1991) Clinical pharmacokinetics of N-acetylcysteine. Clin Pharmacokinet 20(2):123-134

James LP, Mayeux PR, Hinson JA (2003) Acetaminophen-induced hepatotoxicity. Drug Metab Dispos 31(12):1499-1506

James LP, Letzig L, Simpson PM, Capparelli E, Roberts DW, Hinson JA, Davern TJ, Lee WM (2009) Pharmacokinetics of acetaminophen-protein adducts in adults with acetaminophen overdose and acute liver failure. Drug Metab Dispos 37(8):1779-1784

Jones AL (1998) Mechanism of action and value of $\mathrm{N}$-acetylcysteine in the treatment of early and late acetaminophen poisoning: a critical review. J Toxicol Clin Toxicol 36(4):277-285

Jones AF, Vale JA (1993) Paracetamol poisoning and the kidney. J Clin Pharm Ther 18(1):5-8

Joyce CW, Kelly JC, Carroll SM (2014) The 100 top-cited classic papers in hand surgery. J Plast Surg Hand Surg 48(4):227-233

Kanter MZ (2006) Comparison of oral and i.v. acetylcysteine in the treatment of acetaminophen poisoning. Am J Health Syst Pharm 63(19):1821-1827

Kao LW, Kirk MA, Furbee RB, Mehta NH, Skinner JR, Brizendine EJ (2003) What is the rate of adverse events after oral $\mathrm{N}$-acetylcysteine administered by the intravenous route to patients with suspected acetaminophen poisoning? Ann Emerg Med 42(6):741-750

Keays R, Harrison PM, Wendon JA, Forbes A, Gove C, Alexander GJ, Williams R (1991) Intravenous acetylcysteine in paracetamol induced fulminant hepatic failure: a prospective controlled trial. BMJ 303(6809):1026-1029

Kelly GS (1998) Clinical applications of N-acetylcysteine. Altern Med Rev 3(2):114-127

Kerr F, Dawson A, Whyte IM, Buckley N, Murray L, Graudins A, Chan B, Trudinger B (2005) The Australasian clinical toxicology investigators collaboration randomized trial of different loading infusion rates of $\mathrm{N}$-acetylcysteine. Ann Emerg Med 45(4):402-408

Khandelwal N, James LP, Sanders C, Larson AM, Lee WM (2011) Unrecognized acetaminophen toxicity as a cause of indeterminate acute liver failure. Hepatology 53(2):567-576 
Kortsalioudaki C, Taylor RM, Cheeseman P, Bansal S, Mieli-Vergani G, Dhawan A (2008) Safety and efficacy of $\mathrm{N}$-acetylcysteine in children with nonacetaminophen-induced acute liver failure. Liver Transplant 14(1):25-30

Kozer E, Evans S, Barr J, Greenberg R, Soriano I, Bulkowstein M, Petrov I, Chen-Levi Z, Barzilay B, Berkovitch M (2003) Glutathione, glutathionedependent enzymes and antioxidant status in erythrocytes from children treated with high-dose paracetamol. Br J Clin Pharmacol 55(3):234-240

Larson AM (2007) Acetaminophen hepatotoxicity. Clin Liver Dis 11(3):525-548

Larson AM, Polson J, Fontana RJ, Davern TJ, Lalani E, Hynan LS, Reisch JS, Schiodt FV, Ostapowicz G, Shakil AO, Lee WM (2005) Acetaminopheninduced acute liver failure: results of a United States multicenter prospective study. Hepatology 42(6):1364-1372

Lauterburg BH, Velez ME (1988) Glutathione deficiency in alcoholics: risk factor for paracetamol hepatotoxicity. Gut 29(9):1153-1157

Lee WM (2004) Acetaminophen and the U.S. Acute Liver Failure Study Group: lowering the risks of hepatic failure. Hepatology 40(1):6-9

Lee WM, Hynan LS, Rossaro L, Fontana RJ, Stravitz RT, Larson AM, Davern TJ II, Murray NG, McCashland T, Reisch JS, Robuck PR (2009) Intravenous $\mathrm{N}$-acetylcysteine improves transplant-free survival in early stage nonacetaminophen acute liver failure. Gastroenterology 137(3):856-864

Lee S, Shin J, Haro M, Khair M, Riboh JC, Kuhns BD, Bush-Joseph CA, Nho SJ (2015) Fifty most cited articles for femoroacetabular impingement and hip arthroscopy. Front Surg 2:41

Lefaivre KA, Shadgan B, O'Brien PJ (2011) 100 most cited articles in orthopaedic surgery. Clin Orthop Rel Res 469(5):1487-1497

Li BZ, Pan HF, Ye DQ (2013) A bibliometric study of literature on SLE research in PubMed (2002-2011). Lupus 22(8):772-777

Loonen MP, Hage JJ, Kon M (2008) Plastic surgery classics: characteristics of 50 top-cited articles in four plastic surgery journals since 1946. Plast Reconstr Surg 121(5):320e-327e

Lynch RM, Robertson R (2004) Anaphylactoid reactions to intravenous $\mathrm{N}$-acetylcysteine: a prospective case controlled study. Accid Emerg Nurs 12(1):10-15

Maclean D, Peters TJ, Brown RA, McCathie M, Baines GF, Robertson PG (1968) Treatment of acute paracetamol poisoning. Lancet 2(7573):849-852

Mahadevan SB, McKiernan PJ, Davies P, Kelly DA (2006) Paracetamol induced hepatotoxicity. Arch Dis Child 91 (7):598-603

Makin AJ, Williams R (1997) Acetaminophen-induced hepatotoxicity: predisposing factors and treatments. Adv Intern Med 42:453-483

Makin AJ, Wendon J, Williams R (1995) A 7-year experience of severe acetaminophen-induced hepatotoxicity (1987-1993). Gastroenterology 109(6):1907-1916

Mant TG, Tempowski JH, Volans GN, Talbot JC (1984) Adverse reactions to acetylcysteine and effects of overdose. Br Med J (Clin Res Ed) 289(6439):217-219

Marzullo L (2005) An update of $\mathrm{N}$-acetylcysteine treatment for acute acetaminophen toxicity in children. Curr Opin Pediatr 17(2):239-245

Mazer M, Perrone J (2008) Acetaminophen-induced nephrotoxicity: pathophysiology, clinical manifestations, and management. J Med Toxicol $4(1): 2-6$

McClain CJ, Price S, Barve S, Devalarja R, Shedlofsky S (1999) Acetaminophen hepatotoxicity: an update. Curr Gastroenterol Rep 1(1):42-49

Millea PJ (2009) N-acetylcysteine: multiple clinical applications. Am Fam Physician 80(3):265-269

Mitchell JR, Jollow DJ, Potter WZ, Davis DC, Gillette JR, Brodie BB (1973a) Acetaminophen-induced hepatic necrosis. I. Role of drug metabolism. J Pharmacol Exp Ther 187(1):185-194

Mitchell JR, Jollow DJ, Potter WZ, Gillette JR, Brodie BB (1973b) Acetaminophen-induced hepatic necrosis. IV. Protective role of glutathione. J Pharmacol Exp Ther 187(1):211-217

Mitchell JR, Thorgeirsson SS, Potter WZ, Jollow DJ, Keiser H (1974) Acetaminophen-induced hepatic injury: protective role of glutathione in man and rationale for therapy. Clin Pharmacol Ther 16(4):676-684

Mitchell I, Bihari D, Chang R, Wendon J, Williams R (1998) Earlier identification of patients at risk from acetaminophen-induced acute liver failure. Crit Care Med 26(2):279-284

Mowry JB, Spyker DA, Brooks DE, McMillan N, Schauben JL (2015) 2014 annual report of the American Association of Poison Control Centers' National Poison Data System (NPDS): 32nd annual report. Clin Toxicol 53(10):962-1147
Murphy R, Swartz R, Watkins PB (1990) Severe acetaminophen toxicity in a patient receiving isoniazid. Ann Intern Med 113(10):799-800

Mutimer DJ, Ayres RC, Neuberger JM, Davies MH, Holguin J, Buckels JA, Mayer AD, McMaster P, Elias E (1994) Serious paracetamol poisoning and the results of liver transplantation. Gut 35(6):809-814

Nourjah P, Ahmad SR, Karwoski C, Willy M (2006) Estimates of acetaminophen (paracetomal)-associated overdoses in the United States. Pharmacoepidemiol Drug Saf 15(6):398-405

O'Grady JG, Wendon J, Tan KC, Potter D, Cottam S, Cohen AT, Gimson AE, Williams $R$ (1991) Liver transplantation after paracetamol overdose. BMJ 303(6796):221-223

Oh YS, Galis ZS (2014) Anatomy of success: the top 100 cited scientific reports focused on hypertension research. Hypertension 63(4):641-647

Pakravan N, Waring WS, Sharma S, Ludlam C, Megson I, Bateman DN (2008) Risk factors and mechanisms of anaphylactoid reactions to acetylcysteine in acetaminophen overdose. Clin Toxicol 46(8):697-702

Penna A, Buchanan N (1991) Paracetamol poisoning in children and hepatotoxicity. Br J Clin Pharmacol 32(2):143-149

Perry HE, Shannon MW (1998) Efficacy of oral versus intravenous N-acetylcysteine in acetaminophen overdose: results of an open-label, clinical trial. J Pediatr 132(1):149-152

Prescott LF (1981) Treatment of severe acetaminophen poisoning with intravenous acetylcysteine. Arch Intern Med 141(3):386-389

Prescott LF (1983) Paracetamol overdosage. Pharmacological considerations and clinical management. Drugs 25(3):290-314

Prescott LF (2000) Paracetamol: past, present, and future. Am J Ther 7(2):143-147

Prescott L (2005) Oral or intravenous $\mathrm{N}$-acetylcysteine for acetaminophen poisoning? Ann Emerg Med 45(4):409-413

Prescott LF, Critchley JA (1983) The treatment of acetaminophen poisoning. Annu Rev Pharmacol Toxicol 23:87-101

Prescott LF, Newton RW, Swainson CP, Wright N, Forrest AR, Matthew H (1974) Successful treatment of severe paracetamol overdosage with cysteamine. Lancet 1(7858):588-592

Prescott LF, Sutherland GR, Park J, Smith IJ, Proudfoot AT (1976) Cysteamine, methionine, and penicillamine in the treatment of paracetamol poisoning. Lancet 2(7977):109-113

Prescott LF, Park J, Ballantyne A, Adriaenssens P, Proudfoot AT (1977) Treatment of paracetamol (acetaminophen) poisoning with $\mathrm{N}$-acetylcysteine. Lancet 2(8035):432-434

Prescott LF, Illingworth RN, Critchley JA, Stewart MJ, Adam RD, Proudfoot AT (1979) Intravenous $N$-acetylcystine: the treatment of choice for paracetamol poisoning. Br Med J 2(6198):1097-1100

Prescott LF, Donovan JW, Jarvie DR, Proudfoot AT (1989) The disposition and kinetics of intravenous $\mathrm{N}$-acetylcysteine in patients with paracetamol overdosage. Eur J Clin Pharmacol 37(5):501-506

Prince MI, Thomas SH, James OF, Hudson M (2000) Reduction in incidence of severe paracetamol poisoning. Lancet 355(9220):2047-2048

Proudfoot AT, Prescott LF (2009) Henry Matthew: the father of modern clinical toxicology. J R Coll Physicians Edinb 39(4):357-361

Riggs BS, Bronstein AC, Kulig K, Archer PG, Rumack BH (1989) Acute acetaminophen overdose during pregnancy. Obstet Gynecol 74(2):247-253

Robert C, Saenz-Feijoo R, Gaudy JF, Arreto CD (2009) Quantitative analysis of the scientific literature on acetaminophen in medicine and biology: a 2003-2005 study. Fundam Clin Pharmacol 23(2):159-168

Rumack BH (1984) Acetaminophen overdose in young children. Treatment and effects of alcohol and other additional ingestants in 417 cases. Am J Dis Child 138(5):428-433

Rumack BH (1986) Acetaminophen overdose in children and adolescents. Pediatr Clin N Am 33(3):691-701

Rumack BH (2002) Acetaminophen hepatotoxicity: the first 35 years. J Toxicol Clin Toxicol 40(1):3-20

Rumack BH, Bateman DN (2012) Acetaminophen and acetylcysteine dose and duration: past, present and future. Clin Toxicol 50(2):91-98

Rumack BH, Matthew H (1975) Acetaminophen poisoning and toxicity. Pediatrics 55(6):871-876

Rumack BH, Peterson RG (1978) Acetaminophen overdose: incidence, diagnosis, and management in 416 patients. Pediatrics 62 (5 Pt 2 Suppl.):898-903

Rumack BH, Peterson RC, Koch GG, Amara IA (1981) Acetaminophen overdose. 662 cases with evaluation of oral acetylcysteine treatment. Arch Intern Med 141(3):380-385 
Rutter KJ, Ubhi T, Smith D, Kitching G, Waring WS (2013) Reported dose as a measure of drug exposure after paracetamol overdose in children. Curr Clin Pharmacol 8(2):164-168

Samuni Y, Goldstein S, Dean OM, Berk M (2013) The chemistry and biological activities of $\mathrm{N}$-acetylcysteine. Biochim Biophys Acta 1830(8):4117-4129

Sandilands EA, Bateman DN (2009) Adverse reactions associated with acetylcysteine. Clin Toxicol 47(2):81-88

Schiodt FV, Rochling FA, Casey DL, Lee WM (1997) Acetaminophen toxicity in an urban county hospital. N Engl J Med 337(16):1112-1117

Schiodt FV, Lee WM, Bondesen S, Ott P, Christensen E (2002) Influence of acute and chronic alcohol intake on the clinical course and outcome in acetaminophen overdose. Aliment Pharmacol Ther 16(4):707-715

Schmidt LE, Dalhoff K (2001) Risk factors in the development of adverse reactions to $\mathrm{N}$-acetylcysteine in patients with paracetamol poisoning. $\mathrm{Br} J$ Clin Pharmacol 51(1):87-91

Schmidt LE، Dalhoff K, Poulsen HE (2002) Acute versus chronic alcohol consumption in acetaminophen-induced hepatotoxicity. Hepatology 35(4):876-882

Seeff LB, Cuccherini BA, Zimmerman HJ, Adler E, Benjamin SB (1986) Acetaminophen hepatotoxicity in alcoholics. A therapeutic misadventure. Ann Intern Med 104(3):399-404

Sivilotti ML, Yarema MC, Juurlink DN, Good AM, Johnson DW (2005) A risk quantification instrument for acute acetaminophen overdose patients treated with $\mathrm{N}$-acetylcysteine. Ann Emerg Med 46(3):263-271

Slattery JT, Wilson JM, Kalhorn TF, Nelson SD (1987) Dose-dependent pharmacokinetics of acetaminophen: evidence of glutathione depletion in humans. Clin Pharmacol Ther 41(4):413-418

Smilkstein MJ, Knapp GL, Kulig KW, Rumack BH (1988) Efficacy of oral $\mathrm{N}$-acetylcysteine in the treatment of acetaminophen overdose. Analysis of the national multicenter study (1976-1985). N Engl J Med 319(24):1557-1562

Smilkstein MJ, Bronstein AC, Linden C, Augenstein WL, Kulig KW, Rumack BH (1991) Acetaminophen overdose: a 48-hour intravenous N-acetylcysteine treatment protocol. Ann Emerg Med 20(10):1058-1063

Thomas SH (1993) Paracetamol (acetaminophen) poisoning. Pharmacol Ther 60(1):91-120

Thompson G, Fatima SB, Shah N, Kitching G, Waring WS (2013) Impact of amending the acetylcysteine marketing authorisation on treatment of paracetamol overdose. ISRN Toxicol 2013:494357

Thomson Reuters (2015) 2014 Journal Citation Reports ${ }^{\circledR}$. http://www.isiknowledge.com. Accessed 13 Nov 2015

Underhill TJ, Greene MK, Dove AF (1990) A comparison of the efficacy of gastric lavage, ipecacuanha and activated charcoal in the emergency management of paracetamol overdose. Arch Emerg Med 7(3):148-154

Van Noorden R, Maher B, Nuzzo R (2014) The top 100 papers. Nature 514(7524):550-553

Wallace Cl, Dargan PI, Jones AL (2002) Paracetamol overdose: an evidence based flowchart to guide management. Emerg Med J 19(3):202-205

Ward RM, Bates BA, Benitz WE, Burchfield DJ, Ring JC, Walls RP, Walson PD, Alexander J, Bennett DR, Cvetkovich T, Hagino OR, MacLeod SM, Mithani S, Mulinare J, Riley LE, Yaffe SJ, Coté CJ, Meltzer EO, Kearns GL, McCarver DG, Notterman DA, Spielberg SJ, Koteras RJ (2001) Acetaminophen toxicity in children. Pediatrics 108(4):1020-1024

Waring WS (2012) Novel acetylcysteine regimens for treatment of paracetamol overdose. Ther Adv Drug Saf 3(6):305-315

Waring WS, Stephen AF, Malkowska AM, Robinson OD (2008a) Acute acetaminophen overdose is associated with dose-dependent hypokalaemia: a prospective study of 331 patients. Basic Clin Pharmacol Toxicol 102(3):325-328

Waring WS, Stephen AF, Malkowska AM, Robinson OD (2008b) Acute ethanol coingestion confers a lower risk of hepatotoxicity after deliberate acetaminophen overdose. Acad Emerg Med 15(1):54-58

Waring WS, Stephen AF, Robinson OD, Dow MA, Pettie JM (2008c) Lower incidence of anaphylactoid reactions to $\mathrm{N}$-acetylcysteine in patients with high acetaminophen concentrations after overdose. Clin Toxicol 46(6):496-500
Waring WS, Stephen AF, Robinson OD, Dow MA, Pettie JM (2008d) Serum urea concentration and the risk of hepatotoxicity after paracetamol overdose. QJM 101(5):359-363

Whyte IM, Buckley NA, Reith DM, Goodhew I, Seldon M, Dawson AH (2000) Acetaminophen causes an increased international normalized ratio by reducing functional factor VII. Ther Drug Monit 22(6):742-748

Winnike JH, Li Z, Wright FA, Macdonald JM, O'Connell TM, Watkins PB (2010) Use of pharmaco-metabonomics for early prediction of acetaminophen-induced hepatotoxicity in humans. Clin Pharmacol Ther $88(1): 45-51$

Woo OF, Mueller PD, Olson KR, Anderson IB, Kim SY (2000) Shorter duration of oral $\mathrm{N}$-acetylcysteine therapy for acute acetaminophen overdose. Ann Emerg Med 35(4):363-368

Yarema MC, Johnson DW, Berlin RJ, Sivilotti ML, Nettel-Aguirre A, Brant RF, Spyker DA, Bailey B, Chalut D, Lee JS, Plint AC, Purssell RA, Rutledge T, Seviour CA, Stiell IG, Thompson M, Tyberg J, Dart RC, Rumack BH (2009) Comparison of the 20-hour intravenous and 72-hour oral acetylcysteine protocols for the treatment of acute acetaminophen poisoning. Ann Emerg Med 54(4):606-614

Yun EJ, Yoon DY, Kim BN, Min KJ, Kim BY, Ku YJ (2015) Endovascular treatment for extracranial carotid stenosis: a 10-year bibliometric analysis. Vasc Endovasc Surg 49(1-2):16-23

Ziment I (1988) Acetylcysteine: a drug that is much more than a mucokinetic. Biomed Pharmacother 42(8):513-519

Zyoud SH, Awang R, Sulaiman SA, Al-Jabi SW (2010a) Assessing the impact of vomiting episodes on outcome after acetaminophen poisoning. Basic Clin Pharmacol Toxicol 107(5):887-892

Zyoud SH, Awang R, Sulaiman SA, Khan HR, Sawalha AF, Sweileh WM, Al-Jabi SW (2010b) Relationship between serum acetaminophen concentration and $\mathrm{N}$-acetylcysteine-induced adverse drug reactions. Basic Clin Pharmacol Toxicol 107(3):718-723

Zyoud SH, Awang R, Syed Sulaiman SA, Sweileh WM, Al-Jabi SW (2010c) Incidence of adverse drug reactions induced by $\mathrm{N}$-acetylcysteine in patients with acetaminophen overdose. Hum Exp Toxicol 29(3):153-160

Zyoud SH, Awang R, Sulaiman SA, Al-Jabi SW (2011) Impact of serum acetaminophen concentration on changes in serum potassium, creatinine and urea concentrations among patients with acetaminophen overdose. Pharmacoepidemiol Drug Saf 20(2):203-208

Zyoud SH, Awang R, Sulaiman SA (2012) Reliability of the reported ingested dose of acetaminophen for predicting the risk of toxicity in acetaminophen overdose patients. Pharmacoepidemiol Drug Saf 21(2):207-213

Zyoud S, Al-Jabi S, Sweileh W, Awang R (2014a) A bibliometric analysis of research productivity of Malaysian publications in leading toxicology journals during a 10-year period (2003-2012). Hum Exp Toxicol 33(12):1284-1293

Zyoud SH, Al-Jabi SW, Sweileh WM, Awang R (2014b) A bibliometric analysis of toxicology research productivity in Middle Eastern Arab countries during a 10-year period (2003-2012). Health Res Policy Syst 12:4

Zyoud SH, Al-Jabi SW, Sweileh WM (2015a) Worldwide research productivity of paracetamol (acetaminophen) poisoning: a bibliometric analysis (2003-2012). Hum Exp Toxicol 34(1):12-23

Zyoud SH, Al-Jabi SW, Sweileh WM, AI-Khalil S, Zyoud SH, Sawalha AF, Awang R (2015b) The Arab world's contribution to solid waste literature: a bibliometric analysis. J Occup Med Toxicol 10:35

Zyoud SH, Al-Jabi SW, Sweileh WM, Awang R, Waring WS (2015c) Bibliometric profile of the global scientific research on methanol poisoning (1902-2012). J Occup Med Toxicol 10:17

Zyoud SH, Al-Jabi SW, Sweileh WM, Awang R, Waring WS (2015d) Global research productivity of $\mathrm{N}$-acetylcysteine use in paracetamol overdose: a bibliometric analysis (1976-2012). Hum Exp Toxicol 34(10):1006-1016 